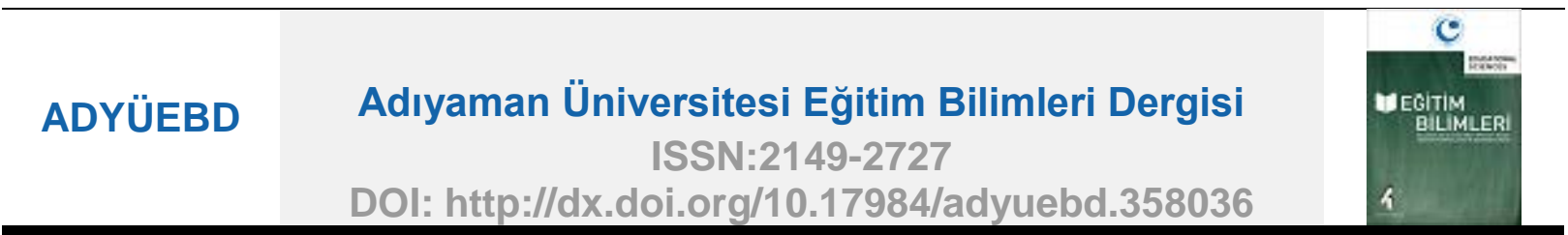 \\ 2013 Okul Öncesi Programının Değerler Eğitimi Açısından Uygulanabilirliğinin Öğretmen Görüşlerine Göre Değerlendirilmesi

\author{
Ali ÜNişEN ${ }^{1 *}$, Hakkı KONTAŞ², Tülay AKDAĞ³
} \\ ${ }^{1,2}$ Adıyaman Universitesi, Eğitim Fakültesi, Adıyaman \\ ${ }^{3}$ Milli Eğitim Müdürlügü, Malatya
}

\begin{tabular}{l} 
MAKALE BİLGí \\
\hline Makale Tarihçesi: \\
Alındı 26.11.2017 \\
Düzeltilmiş hali \\
alındı 25.06.2018 \\
Kabul edildi: \\
27.06.2018 \\
Çevrimiçi yayınlandı \\
30.06.2018
\end{tabular}

30.06.2018

\begin{abstract}
ÖZET
Bu çalışmanın amacı 2013 Okul Öncesi Eğitimi Programını değerler eğitimi açısından incelemektir. Çalışma 90 okul öncesi öğretmeni katıımcıyla nitel yöntemle yapılmıştır. Araştırmacılar tarafından programda bulunan değerler ve literatür taramasıyla tespit edilen aday değerler ile katıımcı görüşlerine göre belirlenen toplam 40 değerin kazandırımasının kazandırılmasına ilişkin öğretmen görüşleri bir anketle alınmıştır. Katılımcılar programda ve uygulamalarında var olan değerleri dört kategoride sınıflandırmışlardır; programda bulunan değerlerden sorumluluk almada gönüllü olma, beden temizliği, kibarılı, yardım isteme, sevgi ve kurallara itaat etmeyi öğretmede sorun yaşamadıklarını ancak iletişim, anlaşma, kendi ve başkalarının haklarını savunma, empati ve sorumluluğunu bilme değerlerini kazandırmada sorun yaşadıklarını belirtmişlerdir. Çevre temizliği, iletişimde kibarlık, paylaşma, hatasını kabul etme, özür dileme, kendini işine verme, yardım teklif etme, işbölümü, grup üyesi olarak hareket etme, emaneti koruma, samimi olma, tutumluluk, saygılı olma, vatan ve bayrak sevgisi, birlik ve beraberlik duygusu programda olmayan ama kazandırılmasında ciddi sorun yaşanmayan değerler arasında sayıldı. Programda bulunmayan, katılımcıların bulunması gerektiğine inandığı ve kazandırılmasında sorun yaşanan son değerler setinde ise zarar vermeden rekabet etme, güzelliği takdir etme, duygularını kontrol etme, barışçı olma, iltifat etme ve cinsel mahremiyetin yer aldığı görüldü. Çalışmanın okul öncesi programlarının geliştirilmesinde değerler eğitimi açısından katkı sağlayacağı düşünülmektedir.
\end{abstract}

(c) 2018 AUJES. Tüm hakları saklıdır

Anahtar Kelimeler:

Okul öncesi programı, değerler eğitimi, değerler eğitimi uygulamaları

\section{Geniş Özet}

Amaç

Bu araştırmanın amacı, 2013 yılında uygulamaya konan okul öncesi eğitim programının değerler eğitimi bağlamında öğretmen görüşlerine dayalı olarak incelenmesidir. Okul öncesi eğitim, çocukların ileriki yaşlarına yansımasını sağlaması bakımından değerler eğitiminde kritik bir öneme sahiptir. Değerler eğitimi ile ilgili araştırmalarda; okul öncesi ile

\footnotetext{
*Sorumlu Yazarın Adresi: Adıyaman Üniversitesi, Eğitim Fakültesi, Adıyaman.

e-posta: aunisen@adiyaman.edu.tr
} 
ilgili yeterince araştırma bulunmadığı görülmektedir. Bu araştırma bir yandan 2013 Okul Öncesi Eğitimi Programının değerler eğitimine ne kadar yer verdiğini, diğer yandan okul öncesi öğretmenlerinin değerler eğitimi ne kadar uyguladıklarını araştırmaktır. Bu araştırmanın; okul öncesi programının değerler eğitimi açısından gelişmesine katkı sağlayacağı düşünülmektedir.

\section{Yöntem}

Bu araştırma 2013 yılında uygulamaya konan okul öncesi eğitim programının değerler eğitimi açısından uygulanabilirliğinin öğretmen görüşlerine değerlendirilmesini ortaya çıkarmayı amaçlayan betimsel desende ve nitel bir çalışmadır. Nitel araştırmalar, varsayımlarla ve bireyler veya grupların bir sosyal ya da insan sorununa atfettikleri anlamlara değinen ve araştırma problemlerinin incelenmesini içeren yorumlayıcı araştırmalardır (Creswell, 2013).

Bu araştırmanın çalışma grubunu, 2014-2015 eğitim-öğretim yılında Şanlıurfa ili Viranşehir ilçesinde bulunan Milli Eğitim Bakanlığına bağlı olarak görev yapan 90 okul öncesi öğretmeni oluşturmaktadır.

Araştırmanın verilerini toplamak amacıyla 2013 okul öncesi eğitim programı ve ilgili alanyazın incelemesi yapılarak araştırmacılar tarafından bir anket formu hazırlanmıştır. Bu anketin hazırlık aşamasında okul öncesi öğrencilerinin gelişimsel özellikleri göz önünde bulundurularak kazandırılabilecek değerler ile ilgili maddeler de ankete ilave edilerek madde havuzu oluşturulmuştur. Anketteki madde havuzu bir uzman psikolojik danışman ve bir eğitim psikolojisi uzmanı tarafından gözden geçirilerek son şekli verilmiş ve anket 40 madde olarak belirlenmiştir.

\section{Bulgular}

Araştırmadan elde edilen bulgulara göre, sorumluluk almada istekli olma, beden temizliği, nezaket, yetişkinlerden yardım isteme, sevgi ve kurallara uymayı öğrenme değerlerinin kazandırılmasında öğretmenlerin büyük bir çoğunluğunun sorun yaşamadığı görülmektedir.

İletişim, uzlaşmacı olma, kendi ve başkalarının haklarını savunma, empati ve sorumluluklarını yerine getirmeyi öğrenme değerlerinin kazandırımasında öğretmenlerin büyük bir çoğunluğunun sorun yaşadığı görülmektedir.

Çevre temizliği, iletişimde nezaket, paylaşım, hatasını kabul etme, özür dileme, bir işe yoğunlaşma, özrü kabul etme, yardım etme, işbölümü yapabilme, grupla birlikte hareket etme, emaneti koruma, samimi ve güven verici olma, tutumlu olma, saygılı olma, vatan ve 
bayrak sevgisi ile birlik ve beraberliği öğrenme değerlerinin kazandırılmasında öğretmenlerin büyük bir çoğunluğunun sorun yaşamadığı belirlenmiştir.

Zarar vermeden rekabeti öğrenme, güzelliklere değer verme, duygularını kontrol etmeyi öğrenme, barışçıl olma, iltifat edebilme ve cinsel gösterişsizliği öğrenebilme değerlerinin kazandırılmasında öğretmenlerin büyük bir çoğunluğunun sorun yaşadığı görülmektedir.

\section{Sonuç ve Tartışma}

Bu araştırmanın sonuçları, 2013 okul öncesi eğitim programında yer almakla birlikte uygulamada sorun yaşanan değerlerin iletişim, uzlaşmacı olma, kendi ve başkalarının haklarını savunma, empati ve sorumluluklarını yerine getirmeyi öğrenme olduğunu göstermektedir.

Değerler eğitiminin etkin olarak verilmesi, hedeflenen değerlerin hakim olduğu bir eğitim ortamını, bu değerlerle donanık eğitimcileri ve yine bu değerleri ve yine bu değerleri görme ve yaşama fırsatı veren eğitim yöntemlerini gerektirmektedir. Bu yüzden değerler eğitiminde kullanılacak yöntemler yaşantı merkezli, üründen çok sürece önem veren ve uygulama ağırlıklı olmalıdır. Hedeflenen değerlerin bireylerde kişilik özelliğine dönüşmesi için bu öğeler arasında işbirliği olmalıdır (Yeşil ve Aydın, 2007:15).

Ülkemizde de değerler eğitiminin önemi gittikçe daha iyi anlaşılmakta ve çoğu İı Milli Eğitim Müdürlüğü’nde değerler eğitimi ile ilgili çalışmalar yürütülmektedir. Araştırmamıza katılan öğretmenlerimiz de çalışmalarında değerler eğitimine yer verdiklerini araştırmamızın başında uyguladığımız katıım formunda belirtmişlerdir. Araştırmamızdan elde edilen bulgular, çalışmaya katılan öğretmenlerin işbirliği, paylaşma, adalet, sevgi, şefkat, hoşgörü, doğruluk/ dürüstlük ve merhamet değerlerine sınıf içi etkinliklerde çocuklarla olan iletişimlerinde diğer evrensel değerlerden (nezaket, yardımlaşma, sorumluluk, saygı, sabır) daha az yer verdiklerini göstermiştir. Çalışmaya katılan okul öncesi öğretmenlerine araştırma başında uygulanan katılım formuna verilen cevaplar incelendiğinde, öğretmenlerin değerler eğitimi ile ilgili kısmen bilgi sahibi oldukları belirlenmiştir (Tarkoçin, Berktaş, Uyanık Balat, 2013:11).

Araştırma sonucunda 2013 okul öncesi eğitim programında yer alan çevre temizliği, iletişimde nezaket, paylaşım, hatasını kabul etme, özür dileme, bir işe yoğunlaşma, özrü kabul etme, yardım etme, işbölümü yapabilme, grupla birlikte hareket etme, emaneti koruma, samimi ve güven verici olma, tutumlu olma, saygılı olma, vatan ve bayrak sevgisi ile birlik ve beraberliği öğrenme değerlerinin kazandırılmasında öğretmenlerin büyük bir çoğunluğunun sorun yaşamadığı görülmüştür. 
Kişilik tohumlarının atıldığı ve önemli ölçüde netleştiği ilk çocukluk dönemi değerler eğitimi açısından önemlidir. Genel olarak değerler kişiliğe ve kültüre dönük bir yapıya sahiptir. Kalıtsal olarak nesilden nesile geçme gibi bir özelliğe sahip olmadığı için başlı başına bir eğitim sorunudur. Buna göre değerler eğitiminin istenilen düzeyde yapılması; belirli değerlerle donanık bireylerin yetiştirilmesi için, çocukluk döneminde sağlam bir temelin atıması gerekir. Bireyin toplumsallaşma süreci, gelişim özellikleri, değerlerin yapı ve özellikleri dikkate alındığında değerler eğitiminin bireyin doğumu ile başlaması bir zorunluluk halini almaktadır. Okul öncesi dönemde aile, okul döneminde ise hem aile hem de okul başta olmak üzere medya, arkadaş çevresi gibi bireyi eğitme ve yönlendirme gücüne sahip tüm kişi kurum ve kuruluşlar bu süreçte önemli rol oynamaktadır (Yeşil ve Aydın, 2007:15).

Okul öncesi öğretmenleri sınıf içi etkinliklerinde çocuklarla olan iletişimlerinde değer eğitimini sistemli olarak uygulamalıdır.1996 yılında New York'ta UNICEF merkez büro çalışanlarından 12 eğitimcinin yaptığı toplantıda, çocukların intiyaçlarının karşılanması ve onların daha mutlu ve uzun bir hayata hazırlanması Yaşayan Değerler Eğitim Programı (LVEP) yapılmıştır. Burada tespit edilen her bir değer için ünite oluşturulmuştur. Bu değerler, barış, saygı, sevgi, hoşgörü, dürüstlük, alçakgönüllülük, işbirliği, mutluluk, sorumluluk, sadelik, özgürlük ve dayanışmadır (Tillman, 2000:XII-1;Yiğittir, 2000). 


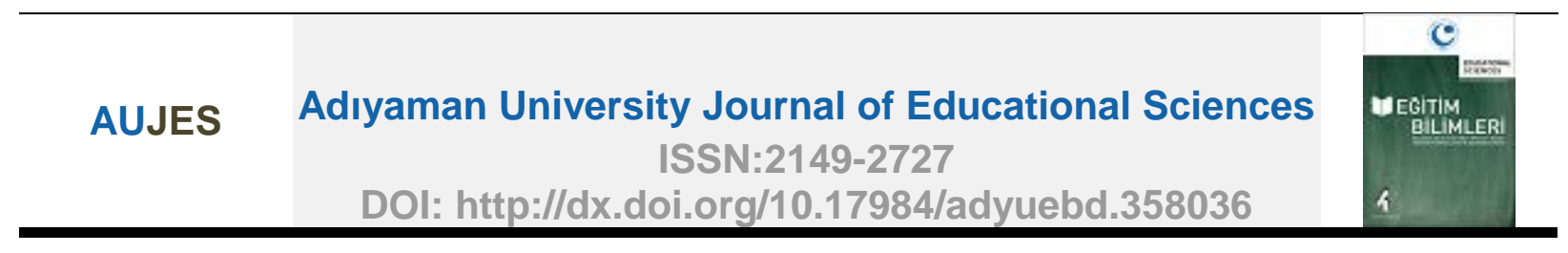

\title{
An Investigation of Turkish 2013 Early-Childhood Curriculum Regarding Values Education: Teacher Views and Practices
}

\begin{abstract}
Ali ÜNIŞEN ${ }^{1 *}$, Hakkı KONTAŞ ${ }^{2}$, Tülay AKDAĞ ${ }^{3}$
${ }^{1,2}$ Adiyaman University Faculty of, Education, Adıyaman

${ }^{3}$ Ministry of Education, Malatya

ARTICLE

INFO

Article History:

Received

26.11.2017

Received in revised

form 25.06.2018

7.06Accepted

27.06.2018

Available

30.06.2018

\section{ABSTRACT}

The study aims to present teachers' views on 2013 Turkish early-childhood curriculum in values education context. It was conducted in qualitative method with 90 preschool teachers. The participants categorized the values in four groups in terms of their existence in the curriculum and their teaching. Of the values exiting in the curriculum, the participants reported that they did not have any difficulty in teaching being voluntary to take responsibilities, physical hygiene, kindness, asking for help, love and learning to obey the rules whereas they had problems in teaching communication, compromising, defending their own rights and of others, empathy and stick to their responsibilities. Environmental cleaning, politeness in communication, sharing, accepting mistakes, apologising, concentrating on duties, accepting apologies, offering help, job-sharing, acting as group members, caring entrusted materials, being sincere, thriftiness, being considerate, love for the country and flag and learning unity and solidarity were counted among the values not existing in the curriculum but the participants had negligible problems in their teaching. The last set of values, which do not exist in the curriculum, but the participant regarded necessary to teach were reported as learning to compete without harming, appreciating beauties, controlling emotions, being peaceful, complimenting and learning sexual privacy.
\end{abstract}

(C) 2018 AUJES. All rights reserved

Keywords:

Turkish early-childhood curriculum, values education, teachers' views and practices

\section{Introduction}

Moral education, character education, ethics education, civic education, citizenship education, social-emotional learning and positive learning are some of the terms used interchangeably to describe values education (Berkowitz \& Bier, 2005; Berkowitz, 2011; Lovat, 2009; The Collaborative for Academic, Social and Emotional Learning (CASEL), 2003). Slightly different emphasizes on specific attainments and whether the content or the process is focused result in that synonymy, or more precisely, multi-denomination. Thornberg (2008), citing from Taylor (1994), states that the term values education is used as an overarching concept to include the attainments of the domain. Raising further discussion on the correct term for the domain is out of scope of the present study.

Programs designed for the domain aim to create schools bringing up ethical, responsible and caring pupils. Social-emotional learning and character education, for example, emphasize common values such as respect, responsibility, honesty, 
fairness, compassion, courtesy and kindness to raise socially and academically developed individuals (CASEL, 2003, p. 5), which overlap with other programs aiming to teach basic human values, core ethical values, core social and individual values (Berkowitz \& Bier, 2005), self-awareness, social awareness, relationship skills and responsible decision making.

The responsibilities in values education tailored for schools in modern new world can be traced back to first quarter of $20^{\text {th }}$ century in secular Turkish education system (Ali Haydar, 1925), however, their role definition has been under discussion since the schools and religious education institutions were charged with revival on values of the nation in 1944 (Cairns, 2005). But Thornberg (2008) argues that values education plays the key role in curriculum writing while dealing with the questions about meaning of human life and the way the society will live together. The endeavor exerted to answer those two questions, in fact, creates the syllabus of value education either explicitly or tacitly, through which students, that is prospective adult citizens, will relate to other counterparts in the same society (Aspin \& Chapman, 2007).

Values education is not preserve of only schools; neither is of families and religious institutions, but schools seem to be functioning better (Teryy Lovat, 2009, p. 10). However, they all have to play their parts in adult competencies which the children are expected to need (Ispa, 2002; Nikolaeva \& Popova, 2014). As schools address to the society as a whole, that function becomes a vital responsibility. The rationale for schools' responsibility in values education evolve out of the facts that schools and teachers within are the major influences on developing values and thus present and prospective society, and schools themselves, being the society, reflect and embody the values of society they are in (Halstead, 2005). Moreover education has always been a values based activity both in philosophy and in operation (Aspin \& Chapman, 2007, p. xiii). Through both their objectives and the way they implement the programs, schools build not only a caring society but justify their present and future patterns.

The studies conducted in recent decades show that the education implemented under the overarch of values education produces more than it is intended for. It was observed to not only prepare students to learn but increase their capacities to learn. Increased mastery of subject, motivated to learn, school commitment, devotion to schoolwork, better attendance, higher grades, higher expectations from the future are shown among the outstanding by-products of the domain education (CASEL, 2003). Greater attachment to school lead to better academic performance and thus to success in school and later life (Turney \& McLanahan, 2015).

Policymakers have put a greater emphasis on early childhood education for many reasons as studies in neuroscience showed that early childhood education is a critical stage for brain development; early childhood programs has a positive impact on future development of individuals; its benefits outweigh the cost and its contribution in reducing educational inequalities (Cortazar, 2015). As a result, they have expanded both their target population and taken measures to improve the quality of programs.

Constant revision and development of programs is necessitated by dynamic characteristic of curriculum development. The changes are triggered and sometimes dictated by a number of social, international, technological and intellectual factors. 
While these factors change or develop on the content, they concurrently exert destabilizing effects on prevalent values. Aspin and Chapman (2007, p. xiii) argue that the chronical problems of communication age and modern world has led individuals to a dependence on the powerful and pervasive media, and the media, while playing its explicit role, tend to decrease their human sensitivities, thus unduly influence their perceptions and actions. The interrelation between perceptions, behaviors, attitudes, decisions, norms and values (Cascio \& Plant, 2015; Hansson, 2001, pp. 15-16; Kılıç, 2012) involves an isotropic development; however, the most two prominent pioneers in moral development, Kohlberg and Piaget, emphasize on intensions and reasons to display a behavior (Duska, 1975, p. 42).

Early childhood education period seems to be the most critical regarding values education (Balat \& Dağal, 2009) as pupils are first introduced with a definite part of the society in which they will live then on. In Durkheim's words (1925), the concepts such as discipline, responsibility, penalty, impersonal rules, esthetics and social attachment construct a new altruistic atmosphere through school socialization. Values, the core elements of socialization, however, are not uniform; they vary from a society or group to another and over the time (Halstead, 2005; Şişman, 2007, p.11). The dynamic aspect of programs involves immediate response to changes.

Turkey has been implementing centralist instructional programs since its establishment in many disciplines. But in social subjects, the lower the stage or grade is, the less rigid the curriculum fidelity is. Teachers are presented themes and subject names alongside the attainments, and freedom to create content locally proper. As to values education, it is intended to be implemented embedded within other activities.

The previous pre-school education program was expostulated due to its inadequate emphasize on values (Üner, 2011; Yazar \& Erkuş, 2013). The current program, intended to remedy the deficits of its antecedent, was introduced in 2013 and the literature still lacks of its feedbacks. It contains 15 basic values with their performance indicators to measure their development besides various activities supporting physical, intellectual, emotional development and preparing them to primary education. The values education is not addressed a separate subject, but embedded in other educational activities. The present paper aims at eliciting teachers' views on adequacy, efficacy and applicability of current pre-school program in aspect of values education. As the study partly focuses on the local values, it will provide vision for the preschool teachers with design content in the curricular framework.

\section{Method}

The present study explores teachers' views about applicability of early childhood program deployed in 2013 in terms of values education. The study was conducted in a descriptive design and qualitative method. Qualitative researches are interpretive studies dealing with the meaning attributed by an individual or groups to any social or individual problem and aim at exploring the research problem (Creswell, 2009).

\section{Participants}

The participants of the study consist of 90 preschool teachers employed at ministerial schools in Viranşehir district of Şanlıurfa province. 
Table 1. Statistics of participants according to their genders

\begin{tabular}{lll}
\hline & $\mathrm{N}$ & $\%$ \\
\hline Female & 80 & 88.9 \\
Male & 10 & 11.1 \\
Total & 90 & 100.0 \\
\hline
\end{tabular}

Table 2. Descriptive statistics dealing with the participants' teaching experiences

\begin{tabular}{ccc}
\hline Experience & $f$ & $\%$ \\
\hline 1 & 38 & 42.2 \\
2 & 13 & 14.4 \\
3 & 22 & 24.4 \\
4 & 6 & 6.7 \\
5 & 2 & 2.2 \\
6 & 4 & 4.4 \\
7 & 2 & 2.2 \\
8 & 1 & 1.1 \\
9 & 1 & 1.1 \\
10 & 1 & 1.1 \\
Total & 90 & 100 \\
\hline
\end{tabular}

The teachers with 1 to 3 years teaching experience comprise $81.1 \%$, and remaining $18.9 \%$ has teaching experiences of 4 years and more.

\section{Data Collection Tool}

A questionnaire was developed by the researchers following the review of 2013 early childhood curriculum and related literature. At preparation stage of the survey, developmental characteristics of pre-school children were taken into account and an items pool which contained items about attainable values was created. The items pool in the questionnaire was revised by experts in psychological counsellorship and education psychology, and it took its last form of 40 items. 15 of the items (namely; 1, 2, 5, 7, 8, 9, 12, 13, 15, 16, 17, 28, 36, 37) were coined from the already existing values in the curriculum while remaining 25 were created from the common decision of the preschool teachers interviewed.

The data collection instrument was a 5-likert-type questionnaire. Participants chose their answers by ticking off "I agree completely, mainly, sometimes, rarely and never" for which they got 5, 4, 3, 2 and 1 point respectively.

\section{Findings}

Table 3. Teachers' views about the values which exist and thought to be attainable in 2013 early childhood program

Values which exist in program and applied without any problem

1. Learning the necessity of completing a task on time

2. Learning to care their physical cleaning

5. Learning to observe the politeness

8. Learning to ask for help from elders when having problems in solving problems of other people

15. Learning to manage to start a work on their own will and finish it on time

16. Being voluntary in assuming responsibilities and learning to fulfill them

28. Learning to express like, favorable emotions

36. Believing in necessity of rules and observing the rules when they contradict their will

Examination of Table 3 shows that teachers do not report that the children experience problems in attaining values as assuming responsibilities, caring their physical cleaning, learning to behave politely, asking for help when needed, expressing their positive emotions and observing the rules, thus, they describe the values in the table as attainable values existing in the program. 
Table 4. Values Existing in 2013 Preschool Program in Application of Which Teacher Experience Difficulties Values Existing in Program with Application Difficulties

7. Learning to solve their problems with others through talking to them

9. Learning to behave reconciliatory when needed

12. Learning to explain their for-against opinions about any subject using proper positive words

13. Learning what to do when faced unfairness

14. Learning what to do to protect others' rights

17. Learning to understand others' feelings

37. Learning to foresee what will happen when shirking their duty and learning to fulfill their responsibilities

Table 4 shows that majority of teacher experience difficulties while helping their students attain the values such as communication, being accommodationist, protecting their own rights and others', developing empathy and learning to fulfill their responsibilities.

Table 5. Teacher Views about the Values Not Existing in 2013 Preschool Program but Applied without Difficulties

3. Learning to care environmental cleaning

4. Learning to use politeness phrases while communicating their friends

6 . Learning to wait for their turn to talk about any subject

19. Learning to share their goods

20. Learning to accept their fault when they are faulty

21. Learning to apologize from their friends when they are faulty

24. Learning to focus on a task

26. Learning to accept their friends' apologizes

27. Learning to help their friends when needed

29. Learning to share the work in a group and fulfill their tasks

30. Learn to act with their friend in the group

31. Learn to keep anything entrusted

32. Learning to be frank and trustworthy in their emotions and behaviors

33. Learning to use their goods as needed, avoid wasting

34. Learning to respect elders

38. Learning devotion to their nation

39. Learning love for national flag

40. Learning the significance of unity

Table 5 shows that the majority of teachers experience difficulties while helping their students learn the values of environmental cleaning, politeness in communication, sharing their goods, accept their faults, apologizing, focusing on a duty, accepting one's apologize, helping their friends, sharing between group members, taking joint action, keeping the goods trusted, being frank and trustworthy, sparing, showing respect, developing love for country and national flag and learning the significance of national unity.

Table 6. Teacher View Regarding 2013 Not Existing and Hard Attainable Values in 2013 Early Childhood

Not-Existing and Hard Attainable Values of the Program

10. Learning envy and competition without harming their friends

11. Learning to be aware of the pleasant and unpleasant things around and appreciate pleasant things

18. Learning to manage their anger

22. Learning to cope with a shameful situation

23. Learning to keep out of quarrels

25. Learning to compliment their friends

35. Learning sexual privacy 
$44,44 \%$ of the teachers report that they have difficulties in helping their students attain the values such as learning envy without harming their classmates, appreciating pleasant things, managing their emotions, being peaceful, paying compliment their friends and learning sexual privacy at various levels.

\section{Conclusion and Discussion}

Results of the present research show that the values which exist and pose difficulties in application in 2013 early childhood program are learning communication, being reconciliatory, defending their own and others' rights, showing empathy towards others and fulfilling their responsibilities.

An effective values education calls for an educational atmosphere in which the target values are also prevalent, educators devised with those values and teaching methods which exhibit and give the opportunity to experience these values. Then, the methods to be used in values education have to be experience centered, prioritize practice and the process rather than the output. There have to be cooperation/coherence between these elements in order that these target values take the form of personal traits (Yeşil \& Aydın, 2007).

Significance of values education becoming more and apparent in Turkey and many provincial directorates for national education conduct researches on values education. The participants of the present study also stated that the values education had a significant coverage in their teaching activities according to their replies to the items on the data collection questionnaire. According to the finding of the study, the participants allotted fewer activities for cooperation, sharing, fairness, love, affection, tolerance, honesty and mercy than other universal values namely politeness, helping each other, responsibility and patience. The examination of the answers for the items in the participation questionnaires showed that the early childhood education teachers had partly knowledge about the values education (Tarkoçin, Berktaş, Uyanık Balat, 2013:11).

Of the values existing in 2013 early childhood education program, learning environmental cleaning, politeness in communication, sharing, accepting their faults, apologizing, focusing on a duty, accepting one's apologize, helping each other, jobsharing, acting as a group member, keeping any good entrusted, being frank and trustworthy, avoiding wasting, learning to respect, learning the love for country and national flag and significance unity were reported to be experienced difficulties by majority of participant teachers.

Learning to compete without harming their partners, appreciating pleasurable things, managing their emotions, being peaceable, being able to pay compliments and learning sexual privacy were also reported to be among the values that majority of the teachers experienced difficulties in teaching.

Early childhood period is of great importance regarding values education as the period forms the vital stage in character development. Values generally have an individual and cultural structure. As values are not inherited genetically, they have to be acquired through education. In order to attain a values education at an adequate level, to bring up a generation devised with certain values, children have to receive a sound education which will form basis for future as soon as possible. Socialization of the individuals, their characteristics, structure and features of the values require starting values education as early as birth. Individuals, institutions and organizations such as family in pre-school period, both family and school in school period, media, 
social circle, each of which has an impact on educating and leading power on individuals, play crucial roles in the process (Yeşil \& Aydın, 2007).

Pre-school teachers have to apply values education through their in-class activities and communication with children. In 1996, 12 educators at UNICEF International Coordination Center designed Living Values Education Program (LVEP) to encourage educators to regard education as providing students a philosophy of living, facilitating their general development, in order that they could integrate themselves into society with respect and confidence. They determined the 12 values, namely, freedom, tolerance, cooperation, honesty, love, happiness, peace, respect, unity, simplicity, responsibility and humility of the most significant universal values (Yiğittir, 2000).

\section{References}

Ali Haydar. (1925). Prague International Congress for Secondary Shool Teachers (Orta Mekteb Muallimleri Beyne'I-Milel Prag Kongresi). Istanbul: Matbaa-i Amire.

Aspin, D. N., \& Chapman, J. D. (2007). Values education and lifelong learning. Principles, policies, programmes. Lifelong Learning.

Balat, G. U. \& Dağal, A. B. (2009). Okul öncesi dönemde değerler eğitimi etkinlikleri. Ankara: Kök Yayıncılık.

Berkowitz, M. W. (2011). What works in values education. International Journal of Educational Research, 50(3), 153-158. doi:10.1016/j.jier.2011.07.003

Berkowitz, M. W., \& Bier, M. C. (2005). What Works In Character Education: Character Education Partnership.

Cairns, J. (2005). Morals, Ethics and Citizenship in Contemporary Teaching. In R. Gardner, J. Cairns, \& D. Lawton (Eds.), Education for Values: Morals, Ethics and Citizenship in Contemporary Teaching (pp. 7-26). London: Kogan Page. doi:10.4324/9780203416730

Cascio, J., \& Plant, E. A. (2015). Prospective moral licensing: Does anticipating doing good later allow you to be bad now? Journal of Experimental Social Psychology, 56, 110 116. doi:10.1016/j.jesp.2014.09.009

Cortazar, A. (2015). Long-term Effects of Early Childhood Education on Academic Achievement in Chile. Early Childhood Research Quarterly, (32), 13-22. doi:http://dx.doi.org/10.1016/j.ecresq.2015.01.003

Cresswell, J. W. (2009). Research Design: Qualitative, Quantitative, and Mixed Methods Approaches.Los Angeles:Sage Publications.

Durkheim, É. (1925). L'Éducation Morale. Paris: Libraire Félix Alcan.

Duska, R. W. M. (1975). Moral Development: a guide to Piaget and Kohlberg. New York: Paulist Press.

Halstead, J. M. (2005). Values and Values Education in Schools. In J. M. Halstead \& M. J. Taylor (Eds.), Values in Education and Education in Values (pp. 2-13). London: Taylor \& Francis.

Hansson, S. O. (2001). The Structure of Values and Norms. Cambridge University Press. 
Ispa, J. M. (2002). Russian child care goals and values: From Perestroika to 2001. Early Childhood Research Quarterly, 17(3), 393-413. doi:10.1016/S0885-2006(02)00171-0

Kılıç, A. (2012). The relationship of values in elementary school 4th grade social studies textbook with the attainments and their level of being included in student workbooks. Kuram ve Uygulamada Egitim Bilimleri, 12(2), 1605-1612.

Lovat, T. (2009). Values Education and Quality Teaching: Two Sides of the Learning Coin. In T. Lovat \& R. Toomey (Eds.), Values Education and Qualities Teaching (pp. 1-12). Springer: Springer.

Nikolaeva, A., \& Popova, L. (2014). To the Problem of the Spiritual and Moral Values Formation in Senior Pre-school Children. Procedia - Social and Behavioral Sciences, 146, 271-274. doi:10.1016/j.sbspro.2014.08.127

Şişman, A. (2007). Açılış konuşmaları. Değerler ve Eğitimi Uluslararası Sempozyumu, İstanbul: Değerler Eğitimi Merkezi Yayınları.

Tarkoçin, S., Berktaş, D. T., \& Balat, G. U. (2013). Okul öncesi öğretmenlerinin sınıf içi etkinliklerde çocuklarla olan iletişimlerinde kullandıkları değerlerin incelenmesi. Pegem Eğitim ve Öğretim Dergisi, 3(2), 37-49.

The Collaborative for Academic, Social and Emotional Learning (CASEL). (2003). Safe and Sound: An Educational Leader's Guide to Evidence-Based Social and Emotional Learning (SEL) Programs.

Thornberg, R. (2008). The lack of professional knowledge in values education. Teaching and Teacher Education, 24(7), 1791-1798. doi:10.1016/j.tate.2008.04.004

Turney, K., \& McLanahan, S. (2015). The academic consequences of early childhood problem behaviors. Social Science Research, 54, 131-145. doi:10.1016/j.ssresearch.2015.06.022

Üner, E. (2011). Okul öncesi eğitim programındaki 36-72 aylık çocuklara farklılıklara saygı eğitimi kazandırmanın öğretmen görüşleri doğrultusunda değerlendirilmesi. Yayımlanmamış yüksek lisans tezi, Erciyes üniversitesi Eğitim Bilimleri Enstitüsü. Kayseri.

Yazar, T., \& Erkuş, S. (2013). The Evaluation the Opinions of Pre-school Education Teachers about the Values Education in Pre-school Education Programme. Dicle Üniversitesi Ziya Gökalp Eğitim Fakültesi Dergisi, (20), 196-211.

Yeşin, R. \& Aydın, D. (2007). Demokratik değerlerin eğitimde yöntem ve zamanlama. Türkiye Sosyal Araştırmalar Dergisi, 11(2), 65-84. 